\title{
El personaje de Úrsula en los Coloquios de Baltasar de Collazos: una revisión de las relaciones literarias ${ }^{1}$
}

\author{
Sara Sánchez Bellido \\ Fundación Ramón Menéndez Pidal - Instituto Universitario Menéndez Pidal (UCM) \\ ssbellido@pdi.ucm.es
}

Recepción: 03/12/2013, Aceptación: 26/12/2013, Publicación: 17/12/2014

\section{Resumen}

Desde que Eugenio Asensio relacionara los Coloquios de Baltasar de Collazos con el Lazarillo de Tormes, la mayoría de los estudiosos se han interesado por las conexiones de este texto con la literatura picaresca. Este hecho afecta igualmente al único personaje femenino de la obra, Úrsula, quien puede verse como un antecedente de la pícara del siglo XviI. En este trabajo se revisará el papel de este personaje en relación con la figura de la mujer en la época, la picaresca femenina y la conexión con la celestinesca a partir de la variante aretiniana.

Palabras clave

Aretino; Celestinesca; Collazos; Diálogo; Picaresca

\section{Abstract \\ The Úrsula's Character in Coloquios by Baltasar de Collazos: a Review of the Literary Conections}

Since Eugenio Asensio related the Coloquios by Baltasar de Collazos with the Lazarillo de Tormes, several scholars have been interested in the relationship between this text and

1. Este trabajo ha sido realizado en el marco de las Ayudas para la contratación de Investigadores de Apoyo de la Comunidad Autónoma de Madrid (convocatoria 2007), así como del proyecto IDEAPROMYR: "Inventario, Descripción, Edición crítica y Análisis de textos de prosa hispánica bajomedieval y renacentista. Línea: Diálogos (Fase 3)” (Referencia FFI2012-33903), financiado por el MINECO, y desarrollado por el "Grupo de Estudios de Prosa hispánica bajomedieval y renacentista” de la Universidad Complutense de Madrid. 
picaresque literature. Úrsula, who is the only female character in Collazos' dialogues, could be considered from this perspective as a precedent of the $17^{\text {th }}$ century picara. In this paper, I will focus on this character taking into account the role of women in this period, the feminine picaresque and the bonds with the celestinesque topic through Aretino's version.

\section{Keywords}

Aretino; Celestinesque literature; Collazos; Dialogue; Picaresque literature

Los Coloquios de Baltasar de Collazos se publican en Lisboa en 1568, aunque probablemente la obra fue redactada algunos años antes, entre 1563 y 1564 . Escrita en forma de diálogo, la crítica ha señalado reiteradamente su conexión con la literatura picaresca y la vertiente aretiniana de la celestinesca, ${ }^{2}$ especialmente para el personaje de Úrsula, una cortesana que aparece en los coloquios undécimo a decimosexto y que narrará su vida al resto de interlocutores en tres de ellos. Es precisamente de este personaje de quien se tratará en este trabajo, con el objeto de comprobar en qué medida responde o no a dichos moldes.

No cabe duda de que el caso de Úrsula es singular. Para empezar, es una mujer y aunque Ana Vian ha puesto de relieve en varios trabajos el papel de la interlocutora en la historia del diálogo, ${ }^{3}$ su aparición aún resulta ocasional, y con frecuencia queda reducida a una función secundaria. ${ }^{4}$ Pero es que, además, no solo conversa, sino que monologa, lo cual parece ciertamente insólito.

La Úrsula de los Coloquios es una mujer «ya de más de cuarenta años y los veinte y siete ha gastado en andar por el mundo, y hartos peruleros se han desembarcado en este río que no han traído registrado, ni por registrar, tanto como esta tiene agora de hazienda». ${ }^{5}$ De su físico poco sabemos, salvo que de joven fue "bonica» ${ }^{6}$ y que la vejez le ha hecho perder esos atributos; una belleza con la que, junto a su gracia personal y la inestimable ayuda de su madre, consiguió

2. Véase Ferrer-Chivite (1998), Gómez (1988: 26, 73 y 128), Peinador Marín (1993) y Vian Herrero (2004 y 2005). Sobre la relación general con la picaresca, puede verse también Sánchez Bellido (2014).

3. Veáse Vian Herrero (2001, y también 1997-1998, 2000, 2004 y 2005).

4. Gómez (1988: 25).

5. Coloquios (2013: 405).

6. Coloquios (2013: 413). 
engatusar y estafar a cuantos se le acercaban. Y es parte de esta vida dedicada a la burla, que le ha deparado una posición económica nada despreciable en la vejez, la que va a narrar a sus homólogos masculinos.

El relato de Úrsula se justifica por la presencia de don Jorge, un caballero flamenco a quien Antonio y Fabián, otros dos de los protagonistas de la obra, llevan ante ella para que descubra uno de los tipos más característicos de Sevilla. Es para satisfacer la curiosidad del extranjero por lo que la interlocutora decide contar algunas de las burlas que realizó en su juventud (siempre bajo la excusa del arrepentimiento y el ejemplo moralizante): selecciona la que realizó a un mercader también flamenco, junto con otra que tuvo lugar simultáneamente, la del toledano, y, por último, una que sufrió en sus propias carnes y que le sirvió de escarmiento (aunque no para abandonar esa vida, sino para ser más cauta) ${ }^{7}$. De ahí que no se cuente toda una vida, sino una serie de episodios que sirvan de ejemplo a sus interlocutores. Es decir, el relato de Úrsula tiene sentido en cuanto parte de la obra completa, de los Coloquios en su conjunto, y de la función que en ellos desempeña, que no es otra que la de reforzar la crítica de la sociedad sevillana (ya presente a lo largo de los anteriores coloquios) e impulsar la conversión definitiva de Antonio, quien se debate entre seguir con su vida de falso caballero o buscar un medio más honrado y provechoso de subsistencia.

Que mujeres como Úrsula existían queda claro por los diferentes testimonios de moralistas y legisladores. Todos tratan de evitar que se produzcan engaños como los que aquí narra nuestra pícara; con este objeto, advierten sobre el comportamiento que deben mantener las mujeres, estas de mala nota, pero también todas las demás. Así, por ejemplo, algunas leyes decidieron un atuendo para las «mujeres públicas» que las distinguiera a simple vista de las «buenas mujeres», lo que obligaba a las primeras a cubrirse con mantos amarillos. ${ }^{8}$

Decir que no era fácil ser mujer en el siglo Xvi es una obviedad, pero no queda más remedio que recordarlo de nuevo aquí. Mientras el varón contribuía al sustento de la familia desde temprana edad, ${ }^{9}$ por lo que se labraba un futuro que le debía garantizar cierta independencia económica, la mujer rara vez ejercía un trabajo remunerado, lo que la convertía en alguien dependiente. Este hecho, sin embargo, no impide que desempeñara un relevante papel social. Sobre ella recaía la responsabilidad del gobierno de la casa y, principalmente, la educación de los hijos, lo que en el caso de las niñas (y de nuevo retomamos lo problemático de su crianza) requería un especial cuidado: una madre despreocupada de la

7. «No cuenta Úrsula toda su vida, pues nadie se lo ha pedido; lo que le solicitan estos interesados varones - Antonio lo hace_- son solo algunas andanzas sevillanas (...). De hecho, la burla del flamenco irá destinada de modo preferente a Don Jorge» (Vian Herrero, 2004: 1433).

8. Ortega, Lavrin y Pérez Cantó (coords.) (2005: 384-385).

9. En el caso de familias de condición humilde, mediante un oficio de tipo manual, y en el de las privilegiadas, con su incorporación al mundo militar o administrativo en muchos casos. 
vigilancia de su hija podía ser la causante de la pérdida de la honra de esta y, con ella, de la de toda la familia. Este es el caso de nuestra Úrsula, quien nos dice:

siendo mi madre viuda y yo mochacha y bonica, començándome a mostrar, no faltó quien me recuestase y pasease la puerta y enviase mensajes, y como nosotras nacemos tan inclinadas a esto y el agujero haze al ladrón, como mi madre se descuidase de mí, anduve de requiebro con un caballero mancebo de aquella ciudad y tuve orden cómo meterle en casa algunas noches, y no pudo ser esto tan secreto que mi madre no lo alcançase a saber; y como vio que el mal recaudo estaba hecho, determinó de lo poner remedio con hazer que este caballero pagase el daño que había hecho; y así, favoreciéndose de las leyes que acerca desto hablan, se le hizo que diese cient mil maravedís por salir de la cárcel. ${ }^{10}$

La ley permitía, en efecto, que las jóvenes que accedieran a mantener relaciones con un varón bajo promesa de matrimonio, si después esta no se cumplía, tuvieran derecho a reclamar e incluso a demandar al joven, para que se dieran los esponsales o bien una compensación económica. En la mayoría de los casos, las familias optaban por la primera solución, ya que suponía una auténtica reparación de la honra perdida. No debe olvidarse que este compromiso se consideraba no solo un paso previo a la boda, sino un inicio del proceso que constituía el contrato matrimonial, por lo que en algunos casos «la promesa de un matrimonio futuro era el marco que posibilitaba entre los jóvenes unas relaciones amorosas e íntimas en un ambiente familiar más relajado respecto a la preocupación de la honra». ${ }^{11}$ Por supuesto, estas situaciones y los problemas que ocasionaban fueron una preocupación constante para la Iglesia y el Estado, que trataron en diversas ocasiones, ya desde la Edad Media, de regular el rito. Preocupaba especialmente el matrimonio secreto, para el que primero van a exigirse testigos y que será prohibido después del Concilio de Trento. Sin embargo, Margarita Ortega señala que las demandas por incumplimiento de esponsales continúan siendo habituales hasta el siglo XVIII ${ }^{12}$ lo que implica que esta práctica estuvo lejos de resultar erradicada.

En el caso de Úrsula, la demanda se resuelve con la petición de una compensación económica, que, como se ha señalado, era otra posibilidad ideada, en principio, para que estas mujeres, que difícilmente encontrarían marido, pudieran costear la dote exigida para su ingreso en un convento. De ello se aprovecha también Elena, la protagonista de la obra de Salas Barbadillo, quien reclama a don Rodrigo de Villafañe,

para entrarme monja, o en dinero de presente o joyas que los valgan, dos mil ducados porque cuando él esta noche con gusto de vuestra merced y todos sus deudos,

10. Coloquios (2013: 413).

11. Ortega, Lavrin y Pérez Cantó (coords.) (2005: 305).

12. Ortega, Lavrin y Pérez Cantó (coords.) (2005: 305). 
me quisiera por mujer, diera de mano al ofrecimiento porque no tengo por seguro hombre tan determinado. ${ }^{13}$

Del mismo modo, la madre de nuestra interlocutora ve en ello una oportunidad de negocio y, marchándose a otra ciudad, donde no es conocido el suceso, «hizo que otros también pagasen el daño que el de Badajoz había hecho, y pudiéralo hazer pagar a muchos más, según se prueba fácilmente un estrupo destos, y como es tan grande esta ciudad, hay gran aparejo para estas cosas». ${ }^{14}$ Así es como la narradora inicia un modo de vida basado en el engaño y en la venta de su propio cuerpo.

De las palabras que se acaban de citar, se deduce que la primera estafa a la que recurrieron madre e hija, una vez en Sevilla, fue la de seguir reclamando a la justicia reparación por la honra perdida. Sin embargo, más adelante va a precisar cómo ambas descubrieron un método más provechoso, el de hacer pagar a los pretendientes de la joven en especie, es decir, en regalos de tipo práctico que garantizasen no solo su supervivencia sino la apariencia de un status social y económico, lo que, a su vez, serviría para atraer a nuevos incautos. Ese es justamente el comportamiento habitual de las pícaras posteriores, cuya obsesión será hacerse pasar por damas, dejando atrás un pasado humilde del que desean escapar. En muchos casos, el objetivo no es otro que el de conseguir un matrimonio provechoso, para lo que necesitan ofrecer una apariencia tanto honesta como acomodada, lo mismo que hará Úrsula, como se verá a continuación. Las pícaras cuidan su imagen, no hay duda, y les funciona en la mayoría de los casos. ${ }^{15}$

Pero, entonces, en el caso de Úrsula, ¿estamos ante una pícara prematura o ante un mero reflejo de un tipo social? Es decir, ¿puede considerársela como una de las primeras representantes de este personaje en la literatura española o deben aceptarse las palabras de Ferrer-Chivite, quien en 1998 señalaba que no deben buscarse en Collazos modelos literarios, sino únicamente tipos comunes de la época? ${ }^{16} \mathrm{He}$ ahí la cuestión que ha centrado algunos de los trabajos de la crítica y que necesariamente debe abordarse.

Las pícaras por excelencia de la literatura española son cuatro: Justina, Elena, Teresa de Manzanares y Rufina. ${ }^{17}$ A ellas se suman en algunos casos los nombres de Flora, Teodora, Feliciana, Luisa, Constanza o Dorotea, protagonistas

13. La hija de Celestina (1986: 153).

14. Coloquios (2013: 413).

15. Ya Rey Hazas señalaba esta característica (1986: 93).

16. Ferrer-Chivite (1998: 208-209).

17. La obra en que aparece Rufina es algo diferente. Pretende ser novela, pero no sigue el esquema de sus predecesoras: está escrita en tercera persona, solo se nos cuentan unas pocas burlas, entrelazadas con la narración de tres novelle, y el final queda abierto anunciando una segunda parte que no llegó a publicarse, por lo que no hay escarmiento para la pícara ni arrepentimiento, y la justificación moral queda en suspenso. 
estas de relatos más breves y más cercanos a la novela cortesana del XVII. ${ }^{18}$ Dado que no toda la crítica está de acuerdo en la inclusión de todas ellas como representantes del género, para el estudio que aquí se presenta, se partirá del pequeño corpus de pícaras mayores con el objeto de limitar el alcance de la comparación.

La tradición crítica ha señalado la autobiografía como uno de los rasgos característicos de la picaresca, generalmente, desde un presente de arrepentimiento más o menos fingido. Para Rey Hazas, por ejemplo, el hecho de que Salas Barbadillo ceda su voz a Elena en el momento en que debe narrarse la procedencia de la joven es signo inequívoco de que el autor la consideraba una pícara y, por tanto, debía ser ella misma quien relatara su prehistoria. ${ }^{19}$

Algo similar ocurre con Úrsula. En este caso, se ha ido presentando a la interlocutora tangencialmente durante la conversación, pero en el momento en que se da paso a la narración de sus aventuras será el único personaje que tome la palabra, permaneciendo el resto de los concurrentes en silencio mientras ella habla. Antes se ha hecho de rogar y finalmente ha recurrido a la excusa de la moralización para asegurar que, si se decide a hablar, es solo para prevenir contra mujeres como ella. El problema es que esta justificación es a todas luces superficial; lo que de verdad parace desear Úrsula es alardear de su ingenio y capacidad para el engaño:

ÚRSULA: Ya yo, señores, he dexado el mundo, gracias a nuestro Señor (...).

Antonio: En todo tiempo se sirve Dios, y en esto que os queda de la vida podríades vivir tan bien y hazer tanta enmienda de lo pasado que mereciésedes que se hubiese Dios con vos (...).

ÚRSULA: Plega a Dios que me dé gracia para que yo lo haga así, y atento a eso, no será razón que yo me acuerde y traiga a la memoria mis travesuras y liviandades pasadas, si no fuere para llorarlas.

FABIÁN: Para eso y también para aprovechar a vuestros próximos oyéndolas, que se guarden de los engańos semejantes.

ÚRSULA: Si para eso es, yo soy contenta de contaros algunas, aunque el que no quisiere ser ahogado en la mar, no navegue, y el que no quisiere que le tome el toro, no entre en el coso, véalo desde la talanquera (...). Así que, el que quisiere ser libre de los engańos y pesadumbres y trabajos que las semejantes que yo he sido dan, huya de tratar con ellas, que no hay otro remedio sino este (...), y para que de veras lo entendáis, os quiero contar algunas cosas de las que por mí han pasado. ${ }^{20}$

Pero cuando termina su narración, ninguna alusión hay a su retiro de esta vida, sino que destaca que "fue Dios servido de tornarme a mi casa y a esta ilustrísima ciudad de Sevilla», ${ }^{21}$ la ciudad donde ha protagonizado sus mejores estafas. Es

18. Son estas las protagonistas de La sabia Flora malsabidilla y Corrección de vicios de Salas Barbadillo y Las harpias en Madrid, de Castillo Solórzano.

19. Rey Hazas (2003: 300).

20. Coloquios (2013: 410-411).

21. Coloquios (2013: 431). 
cierto que la mayoría de las pícaras hacen lo mismo. Tanto Justina como Teresa cuentan su vida sin motivo aparente, como mera reflexión sobre su vida pasada, y, quizás, como ha señalado parte de la crítica, por el mero deseo del autor de utilizar unos modelos genéricos de éxito asegurado. ${ }^{22}$

De todos modos, Úrsula aún no ha asimilado este molde como tal (quizás haya recibido la influencia del Lazarillo, aunque no únicamente de esta obra, como se verá más abajo). En definitiva, ella cuenta su vida en primera persona porque lo exige la forma dialogada y porque se lo piden sus interlocutores. ${ }^{23}$ No obstante, queda claro que a los autores les interesa cada vez más conceder la palabra a estas mujeres, que, una vez establecido el modelo de Justina, poblarán la novela (corta o extensa) del siglo xviI. ${ }^{24}$ Si bien es cierto que Justina debió de ser un modelo fundamental para la construcción del personaje femenino protagonista, no debe olvidarse que otros géneros y textos ya habían comenzado ese camino y habían presentado mujeres con suficiente presencia, carácter e importancia como para ser consideradas si no protagonistas, sí personajes centrales. Es lo que ocurre con Úrsula, pero también con Catalina, Eulalia, Jantipa, Dorotea, Blesilla o Flaminia, esa serie de "cotorras», como las denomina Vian Herrero, que pueblan el diálogo humanístico desde Erasmo. ${ }^{25}$

En la tradición picaresca, la narración se remonta en todos los casos a los orígenes del personaje, su procedencia, la condición de sus padres, etc., que suele remitir a un entorno social deshonesto. Así, los padres de Justina eran mesoneros conversos y su madre, además, alcahueta; los de Elena, un lacayo

22. Véase Rey Hazas, 1986. La mayor parte de la crítica está de acuerdo en que estas obras no presentan realmente a una protagonista arrepentida, pese a que los autores prometen mostrar un personaje escarmentado; en lo que difieren es en la valoración de este hecho. Hanrahan, por ejemplo, dice que «aquí no se trata de arrepentimiento ni de edificación, sino sencillamente de un final feliz» (Hanrahan 1967: II, 245), y Arredondo que "Teresa va acumulando una notable fortuna, sin que el autor la someta a más castigo que las momentáneas turbaciones derivadas de huidas precipitadas, o, al final de la obra, a un último matrimonio mediocre, caracterizado por el término "miseria", que repugnaría a una mujer alegre y deseosa de lucir y gastar. Todo ello puede interpretarse, efectivamente, como fallo del autor a la hora de asumir el punto de vista de la pícara narradora, que no escribe desde un caso fiel de deshonor, sino desde una frustración relativa respecto a unas expectativas inadmisibles; pero también, por el contrario, como una novedad en el patrón picaresco» (2005: 34-35). Este artículo ha tomado como punto de referencia los trabajos de Rey Hazas y Arredondo Sirodey por su continuada dedicación a la literatura picaresca femenina y por ser los responsables de las ediciones generalmente más valoradas, aunque para la preparación del mismo se han tenido en cuenta los trabajos de otros especialistas no incluidos finalmente en la bibliografía final debido a la necesidad de aligerar el volumen de citas.

23. Algo similar observa Carmen Gallardo sobre los Eremitae de Juan de Maldonado: «el texto que nos ocupa cabría ser definido como una serie de relatos autobiográficos engastados en un marco dialogístico o coloquial. (...) aquél que en cada momento toma la palabra para confesar sus experiencias apenas se ve interrumpido por otro interlocutor, de manera que sus intervenciones llegan a ser narraciones más o menos amplias» (Gallardo, 2001: 111).

24. Arredondo Sirodey (2001: 13).

25. Véase Vian Herrero (2000 y 2001). 
borracho y una esclava morisca y hechicera; los de Teresa, un buhonero y otra mesonera; y Rufina es hija de Trapaza, otro pícaro. Úrsula da comienzo a la narración de su vida refiriendo a su vez su procedencia, si bien de forma más somera a lo habitual. No sabemos cuándo nació con exactitud, ni quiénes eran realmente sus padres. Ana Vian nos recuerda que sus orígenes son bajos, como es habitual en la narración autobiográfica del pícaro, ${ }^{26}$ aunque no se alude en el texto a este arranque humilde e infamante. Únicamente explicita que "yo nací en Badajoz, ciudad principal d'Estremadura ${ }^{27}$ y, a continuación, comienza el relato del primer caso, el de la pérdida de su honra. ${ }^{28}$ Así pues, no existe ningún indicio del mundo al que pertenecía antes de comenzar esa vida de mentiras y estafas. Lo único seguro es que «llegadas a esta ciudad [Sevilla], tomamos casa en ella y adereçámosla razonablemente, y començamos a vivir muy honesta y recogidamente, andando yo y tratándome como doncella», ${ }^{29}$ es decir, se instalaron conforme a una posición al parecer de medianía económica. Ese «razonablemente» parece indicar que arreglaron la casa con cierto gusto, a buen seguro de forma no demasiado ostentosa, pero sí con algunas comodidades. Así mismo, más adelante, cuando se cuenta la burla al mercader flamenco, descubrimos que la madre y las dos hijas iban acompañadas de dos amas, ${ }^{30}$ lo que denota una condición, cuando menos, holgada. Sin embargo, también es cierto que el hecho de que la madre acepte con tal facilidad la pérdida de la virtud de la hija parece ser muestra de una laxitud moral nada propia de una ascendencia honrada.

Como ya se ha señalado, la mayoría de las pícaras recurren también a un falso ennoblecimiento para ascender en la escala social, al igual que los pícaros varones. Se trata de nuevo de una simulación a partir de la reproducción de los rasgos externos característicos de los estamentos privilegiados. Frecuentemente se hacen pasar por damas y viudas (nunca por hijas de mercader, por ejemplo) y, para evitar ser descubiertas por quienes conocieran su condición, se mudan, como Úrsula, a mejores barrios o ciudades más grandes. Por ejemplo, Elena, supuesta dama de León, huye de Toledo a Madrid tras estafar a don Rodrigo, y Teresa escapa de Málaga a Granada, entre otros viajes, cuando se descubre su artimaña al capitán, ante quien había simulado ser su hija cautiva. Más tarde, también huye de Toledo a Madrid tras timar a otros dos toledanos.

26. «Úrsula comienza su narración autobiográfica, como los pícaros varones, desde el nacimiento, en Badajoz, reproduciendo varios elementos importantes del género en cuestión: origen humilde e infamante» (Vian Herrero 2005: 461).

27. Coloquios (2013: 413).

28. Al narrar la burla del chocarrero, también nos informa de su apellido, Ruiz (Coloquios 2013: 425), pero no podemos deducir nada de él, puesto que era ya común y por sí solo no garantizaba linaje, además de que cabe la posibilidad de que este sea falso, debido a esa preocupación por fingir la posición.

29. Coloquios (2013: 414).

30. Coloquios (2013: 414). 
En definitiva, como ha puesto al descubierto Rey Hazas, las pícaras se «aburguesan", se convierten en "cortesanas de apariencia». ${ }^{31}$ Un molde en el que también puede encajar Úrsula, puesto que a la imagen engańosa que transmite al mercader flamenco se une la que presenta ante los indianos objeto de sus estafas tras la muerte de la madre: «a la hora que venían las naos de las Indias, a las noches me iba con mis amas muy bien adereçada a Triana y a la Cestería, adonde acuden a posar aquellos portadores deste metal (...). A ellos parecíales muy bien la moça». ${ }^{32}$ Como Teresa, quien además tenía escudero, también la interlocutora se hace servir de esclavas, en este caso regaladas por el flamenco, y se ocupa de vestir adecuadamente: «iba bien apuesta para el propósito» o, «començé a gastar y comprar algunas ropas para mi persona». ${ }^{33}$

Y es que la apariencia adquiere gran relevancia, pues el modo de vida de estas mujerzuelas suele consistir en engañar a hombres que puedan pagar en metálico o especie por su trato e, incluso, desposarse con ellos o fingirse una hija perdida si se da la ocasión, como ya se ha dicho. En definitiva, se sirven de su belleza e ingenio para cautivar a incautos. Uno de sus objetivos es frecuentemente el matrimonio con un caballero rico y, a poder ser, viejo. ${ }^{34}$ Así, Justina nos hablará de sus pretendientes y sus maridos: Lozano, Santolaja y Guzmán de Alfarache. ${ }^{35}$ Teresa, por su parte, se casa cuatro veces, y de ellas, solo una por amor, con Sarabia. El resto de sus maridos son un hidalgo viejo y rico, un indiano y un mercader de cincuenta años. Rufina también se desposa por dinero con un anciano y Flora se transmuta de gitana ramera en toda una dama para casarse con Teodoro y vengarse así de una injuria anterior. En la mayoría de los casos, lo que se busca es la estabilidad económica, un marido o amante que les proporcione las galas y joyas que les gusta lucir. En cambio, Úrsula vende su cuerpo con los mismos fines, pero no menciona que se haya desposado. Ella prefiere el amancebamiento, pues le reporta los mismos beneficios y le garantiza cierta libertad. ${ }^{36}$ No en vano, si hay algo que comparten pícaros y pícaras, además del autobiografismo y el afán de medro social, es ese deseo de libertad. Para Lázaro, la cumbre de su buena fortuna es un oficio de pregonero, que no implica servidumbre; Guzmán pronto abandona el servicio a amos por negocios y «oficios» individuales (mendigo, mercader), Justina se considera mujer libre, Teresa establece negocio propio, Elena vive del beneficio de sus timos y man-

31. Rey Hazas (1986: 90).

32. Coloquios (2013: 423).

33. Coloquios (2013: 427).

34. Cfr. Ray Hazas (1986: 93).

35. «El amor, o el matrimonio (que no siempre van unidos), se une al tema del interés en la vida de las pícaras, que se sirven de su atractivo físico para medrar» (Arredondo Sirodey 1993: 16).

36. Del flamenco obtiene tapicería, cadenas, pulseras, esclavas, todo aquello objeto de sus fingidos antojos, cama y canastilla; del toledano, los vestidos con los que se disfraza y veinte ducados; del chocarrero la cadena, que resulta ser falsa pero ella considera buena ganancia en principio. 
tiene a Montúfar solo cuando le interesa. Esta misma libertad es la que destaca precisamente Soledad Arredondo en Teresa. Se trata no solo de libertad en lo referente a costumbres, sino también de actuación. Son ellas quienes deciden qué hacer, con quién y en qué momento. ${ }^{37}$

En cambio, como se ha mencionado ya, el hambre no les afecta. Esta es también una diferencia entre Úrsula y sus interlocutores. Mientras ellos pasan penurias y se quejan una y otra vez del hambre, ella ha comido cuando llegan a su casa, está en los postres, y los acompaña de buen vino. Parece, además, que no ha sabido nunca lo que es el hambre, ni tan siquiera en la cárcel, donde estuvo dos meses y «nunca mejores los pasé porque era festejada de galanes presos y servida de todo cuanto yo quería».38

Por otro lado, hay una característica de las pícaras que no se encuentra aún en Úrsula: la ambigüedad en cuanto a su virtud. Salvo Elena, el resto de pícaras presume de su castidad (Justina), sucumbe solo a causa del desenamoramiento de su esposo (Teresa) o entretiene a los amantes para culminar la estafa antes de ceder a sus pretensiones (Rufina). Es cierto que este comportamiento aparentemente honesto no lo es en realidad, ya que todas pecan de adúlteras o juegan y disimulan, aunque confiesen entre burlas sus faltas. Sin embargo, Úrsula no lo oculta, comienza su narración por el momento en que perdió su honra y deja patente cómo vive de ello, se permite incluso alternar a sus amantes y elegir a alguno por gusto: «yo, pensando que tenía en él guillote, le dexé dormir algunas noches comigo sin querer dél cosa alguna». ${ }^{39}$ Solo cuando muere su madre decide para su hermana y para sí «estar muy recogidas y que no entrasen hombres en nuestra casa, sino que hubiese en ella todo recogimiento" ; ${ }^{40}$ pero este comportamiento está destinado a preparar la coartada que les servirá después en sus engaños a indianos.

En su caso, además, la madre ejerce no solo de consentidora, sino de auténtico cerebro y guía de conducta para el modo de vida de las dos hijas. Ella es la que urde y dirige la estafa al mercader flamenco, así como la que recomienda a Úrsula que dé una lección al toledano. ${ }^{41} \mathrm{~A}$ la hija no le costará mucho aprender de ella y aun se lamentará de los casos en los que desoyó sus consejos. La pérdida de esta le causará un dolor que recordará años después y desde el presente rememorará con admiración sus dotes para el engaño y la mentira: «ella era la componedora destos engaños así como lo fue Sinón griego para hazer que los troyanos metiesen en su ciudad aquel caballo de madera», «mandó abrir un almazén y mostrarnos mucha tapicería de Bruselas y Malinas, una fina y otra más, y ninguna tanto como mi madre», o «renovóseme el dolor de la muerte de mi madre», dice Úrsula.

37. Arredondo Sirodey (1993: 16 y 23).

38. Coloquios (2013: 429).

39. Coloquios (2013: 415).

40. Coloquios (2013: 423).

41. Coloquios (2013: 414-415). 
Heredera de la tradición celestinesca, esta madre alcahueta se asemeja a la de la cortesana de El Crotalón y, de forma complementaria, a la de Elena. Esta última no solo vendió la virginidad de su hija tres veces, sino que también era conocida hechicera "y así la llamaron todos en voz común 'Celestina', segunda deste nombre». ${ }^{42}$ La de Úrsula la entregará a unos y a otros, ideará el «azeruelo» con el que se finge preńada y resolverá una y otra vez los problemas surgidos durante las burlas. De ahí que la hetaira la califique en varias ocasiones como «sabia» o de "acertado juizio». ${ }^{43}$ Se trata de un elemento más de conexión con la tradición literaria.

Todo lo dicho parece indicar que Úrsula es efectivamente una criatura eminentemente literaria; con un evidente trasfondo real, sí, pero personaje de diálogo al fin y al cabo. Ahora bien, ¿heredera de qué tradición? Se han señalado hasta ahora las semejanzas del personaje con la literatura picaresca, pero también puede (y debe) relacionarse con la tradición celestinesca, como acaba de verse, especialmente la heredada de su vertiente italiana.

Pícara o no, lo cierto es que el modelo directo del que parece haberse servido Collazos para su Úrsula es el de la Lucrecia del Coloquio de las damas, la traducción que Fernán Xuárez realizó de la tercera jornada del Ragionamento de Aretino. ${ }^{44}$ Esta filiación no es en absoluto nueva; ya Peinador y Ferrer-Chivite consideraron al italiano fuente de esta obra, aunque refiriéndose al original y no a la traducción. ${ }^{45}$ Fue Ana Vian, en cambio, quien se encargó de concretar las similitudes entre ambos textos y confirmar que la versión que Collazos conoció fue sin duda la española. ${ }^{46}$

La obra del italiano recogía la tradición del diálogo satírico lucianesco para unirla a la de los diálogos formativos, y parodiar, de este modo, una de las manifestaciones más habituales del género. En los Ragionamenti, Nanna conversa primero con su compañera Antonia sobre qué modo de vida es mejor, si el de monja, el de mujer casada o el de prostituta. Se decide por este último y adoctrina después a su hija, Pippa, sobre el modo correcto de ejercerlo. Heredero de la variante más erótica de la tradición celestinesca, con el modelo como trasfondo

42. La hija de Celestina (1986: 161).

43. Coloquios (2013: 415, 419 y 420).

44. El propio Collazos reconoce la relación en boca de Antonio, quien nos dice: «holgaréis más de verla que a Lucrecia y a Antonia de Roma» (Coloquios 2013: 406).

45. Véase Peinador Marín (1993) y Ferrer-Chivite (1998). También Jesús Gómez señaló la dependencia de los Coloquios con la traducción española, pero no indicó las razones que lo demostraban (Véase Gómez 1988: 26, 73 y 128).

46. «La deuda de Collazos a Xuárez es demostrable gracias a diversos y prolongados préstamos que no sobrepasan la Giornata Terza, por lo que nada autoriza a suponer que hubiera consultado completos y directamente el Ragionamento y el Dialogo. Collazos invierte al modelo italiano y se apoya en el traductor al convertir en relato 'ejemplar' -una ejemplaridad ambigua y singular que sólo lo es como paradoja argumentativa- lo que carecía de este propósito» (Vian Herrero 2005: 458-459. Véanse también 2003 y 2004). 
de la Lozana andaluza, el texto abunda en descripciones, metáforas y términos sexuales, que, sin embargo, se atenuarán en la traducción de Xuárez. El sevillano se decanta por realizar una versión reducida, en la que Lucrecia narra a Antonia algunas de sus peripecias como prostituta, aunque lo hace desde un punto de vista moralizador y notablemente censurado. Amplifica asimismo algunos pasajes y añade comentarios, dichos o refranes, siempre con la misma intención. ${ }^{47}$ Aun así, estos cambios no impidieron que la obra se prohibiera en 1559, si bien también es cierto que su éxito inmediato debió de favorecer que se continuara leyendo y difundiendo durante todo el siglo Xvi, pues en 1607 se imprime de nuevo en una versión clandestina. A su vez, las huellas presentes en obras como los Coloquios de Collazos, El Crotalón o La tía fingida demuestran que su lectura fue aprovechada por diversos autores que, como en el caso de Collazos, jugaban con el posible reconocimiento de la fuente por parte del público. ${ }^{48}$

La cortesana del canto VII de El Crotalón es el primer ejemplo de interlocutora basada en el Aretino español y también «el más precoz relato picaresco femenino en nuestras letras». ${ }^{49}$ No puede decirse que esta sea modelo de la Úrsula de Collazos, pues no es probable que el autor conociera tal precedente, pero ambas coinciden en gran medida en el tratamiento del personaje, lo que remite a la fuente común. En los dos casos lo que se cuenta son engaños de una joven que se hace pasar por dama, en los que se presta más atención a la anécdota del hurto que a las cuestiones eróticas, y en los que las madres de las protagonistas colaboran y gestan las tretas.

Si se examinan más detenidamente las resonancias del texto de Xuárez en los Coloquios, puede apreciarse que las semejanzas más evidentes son las que aparecen en la narración de la burla al mercader flamenco. En el texto aretiniano, Lucrecia simula un embarazo para contentar a un mercader con el que tenía trato y al que hacía creer que él solo era su amante. Este, que deseaba tener un hijo, se vuelca en detalles con la mujer y satisface todos sus antojos, pero ella, para salir del paso, simula un aborto con un corderito no nacido. ${ }^{50}$ Collazos, en cambio, idea que Úrsula engañe al "flamenquito» solo hasta los siete meses, cuando aprovecha un viaje de este para dar lugar al falso parto y fingir la posterior muerte del hijo. La madre, urdi-

47. Véase Fernán Xuárez (2011, especialmente págs.: XV-XXVIII).

48. Cfr. Xuárez (2011: XXXI-XXXIII) y Vian Herrero (2003: 346-349). Véase también la nota 46. 49. Esta cortesana narra sus bajos orígenes y cómo comienza a relacionarse con hombres, lo que le lleva a marcharse como soldadera y a dedicarse a la prostitución encubierta a su regreso a España, siempre bajo el disfraz de dama. De ella viven su madre y su hermano y engañan, entre otros, a un mercader extranjero al que entretienen con promesas hasta sacarle no solo joyas y vestidos, sino también cuatrocientos ducados (Véase Vian Herrero, 1982: II, 218-230 y 1997-1998). También Soledad Arredondo señala esta semejanza de la cortesana de El Crotalón con la celestinesca y la picaresca y concluye que «todo ello indica que empieza a perfilarse un tipo literario femenino procedente de la o las figuras de la mala mujer, en el que van a insertarse elementos picarescos como la crítica social y la narración autobiográfica desde la pre-historia familiar» (Arredondo Sirodey, 1993: 17).

50. Xuárez (2011: 72-74). 
dora del plan, le fabrica una falsa barriga, hace traer a una fingida "maesa» para que la atienda y, en suma, incita al mercader a gastar todo lo que tiene en los antojos, preparativos y agasajos para la parturienta. Del mismo modo, envía a dos mensajeros a su costa para avisarle de las noticias y después consigue que se desviva para sacar a Úrsula de una supuesta depresión. Con todo ello, acaba por arruinar al joven, para olvidarlo después (como Lucrecia abandona a su primer galán en Roma ${ }^{51}$ ):

él se descuidaba de proveer a Flandes y dar recaudo de sus negocios. La nueva fue allá de sus gastos y no tardó mucho que no vinieron a tomarle cuenta, la cual, él tenía tan ruin que dieron con él en la cárcel, de donde el triste me envió hartas vezes a llamar y yo fuera de buena gana, si no se le hubieran acabado los dineros. ${ }^{52}$

La fuente está ahí, no cabe duda, pero Collazos la modifica y amplía, creando un final original que lo separa del modelo. Lo mismo ocurre con la estafa al toledano, a quien convence de que la acompañe a la comedia vestida de hombre y luego le prende y estafa los vestidos y dinero de la multa. En este caso, el episodio recuerda al del Carnaval que narra Lucrecia en el que también busca engañar a un galán que no deseaba compensarla, viste de varón y se queda después con las ropas. Pero se trata tan solo de un recuerdo, ya que el desarrollo de la anécdota es ciertamente diferente. ${ }^{53}$

Más aún queda patente la libertad de creación del palentino en la burla del chocarrero, cuya única semejanza con el original puede ser la mención a una cadena (en ese caso auténtica). Pero, curiosamente, algunos detalles de esta estratagema recuerdan la que realizará Teresa medio siglo después para casarse con el perulero en Sevilla. Úrsula cuenta que, tras la muerte de su madre,

determiné de tomar un modo de vivir que en vida de mi madre había deseado mucho probar, que fue, a la hora que venían naos de las Indias, a las noches me iba con mis amas muy bien adereçada a Triana y a la Cestería, adonde acuden a posar aquellos portadores deste metal que tantos guisados y tan sabrosos se hazen dél, y todos al gusto que hombre desea. Allí me informaba quién era el que más traía y procuraba verme con él con achaque de preguntar por un hermano mío que dezía yo que había mucho tiempo que había pasado al Pirú y que tenía un repartimiento muy bueno de indios en la provincia de las Charcas, y con el que venía de Nueva España, dezía que mi hermano había ido con Pánfilo de Narváez y que, después del desbarate de Narváez por Cortés, se había pasado a la parte de Cortés, como hizieron los demás, y que tenía una mina muy principal en las Çacatecas. A ellos parecíales muy bien la moça y, como venían con deseos, aunque no tantos como yo llevaba de su oro, concertábamonos de presto. ${ }^{54}$

51. Xuárez (2011: 40).

52. Coloquios (2013: 421).

53. Cfr. Xuárez (2011: 126-138) y Vian Herrero (2005: 464, n. 69).

54. Coloquios (2013: 423). 
La pícara madrileña, en cambio, consciente de la afición de su vecino, ideará una historia para atraparle basada en la espera de su tío:

díjole ser hija de un caballero de Castilla muy calificado, el cual había venido a Sevilla en busca de un hermano suyo que estaba en Indias, y le esperaba en la pasada flota. Díjole cómo había muerto allí y dejádome en Sevilla, viuda y moza, esperando a mi tío. Preguntó el indiano en qué parte de las Indias estaba; díjole que en las Filipinas, donde había pasado en compañía de don Alonso Fajardo, gobernador que fue de aquellas partes. Diole crédito a todo el indiano y túvome en más estima de allí adelante. ${ }^{55}$

En este caso, es un letrado amigo quien informa al perulero por mandato de Teresa, que tiene mucho cuidado de no mostrarse demasiado para aumentar su fama de discreta y honrada. Como puede verse, las coincidencias no son exactas, es más bien una semejanza general, en tanto en cuanto ambas mujeres fingen esperar noticias de un familiar que se encuentra en Indias y dan detalles de dónde está y con quién fue. ${ }^{56}$ Dado que es improbable que Alonso Castillo conociera el texto de Collazos, lo más lógico es pensar que este tipo de historias se daban con cierta normalidad, y que de ello se aprovechan ambos autores a la vez para narrar las burlas de sus protagonistas. Se trataría, por tanto, de una feliz coincidencia basada en el uso de unos moldes y modelos comunes; en este caso, la vida en torno a las flotas provenientes de Indias.

En realidad, lo que hace Baltasar de Collazos, de forma aún más clara que el autor de El Crotalón, es aunar la tradición celestinesca con la aretiniana y el nuevo modelo del Lazarillo (que conocía con toda seguridad). ${ }^{57}$ Soledad Arredondo seńaló que, aunque los personajes de la alcahueta y la prostituta eran ya conocidos para el lector, es la aparición del Lazarillo lo que permite que se dé un paso más y estas mujeres se atrevan a contar su propia vida. ${ }^{58}$

55. La niña de los embustes, Teresa de Manzanares (2005: 229).

56. Obviamente, la diferencia temporal impide la coincidencia en el tipo de viaje, pues Teresa escribe en un momento en que el descubrimiento y conquista de las Indias está prácticamente concluido.

57. Algunos de los rasgos que caracterizan a los personajes masculinos de la obra están claramente inspirados por esta obra, especialmente en el caso de Fabián, a quien vemos rosario en mano por la calle, sin alusión alguna a su hora de comer, cuidando de no arrimarse a lugares donde pueda caer polvo a la ropa y quitándosela en cuanto llega a casa para que no desluzca. También él se hace seguir de mozos a los que no paga ni da de comer y que le abandonan en cuanto se les gastan los zapatos de andar tras de él (Cfr. Sánchez Bellido 2014). En definitiva, puede decirse, tomando prestadas las palabras a Eugenio Asensio que «Collazos, que sin duda no sentía vocación por la novela, resolvió sacar a escena los hidalgos del Lazarillo en diálogos de contenido social y moral más que estético. Lejos de esconder la genealogía de sus personajes, ya que no podía mencionar la novela, multiplicó las señales y referencias que apuntaban a la obra de cuyo suelo habían brotado» (Asensio 1973: 387-388).

58. Arredondo Sirodey (1993: 13). 
Así, de Celestina y sus continuadoras habría heredado Úrsula su amor por el vino, además de la connivencia de la madre en unas estafas sexuales que alcanzan la categoría de alcahuetería. De Lázaro, el uso narrativo de la primera persona y la feliz medianía desde la que se cuenta la vida pasada. Del Aretino español, en cambio, es el uso del personaje femenino que se sirve de sus encantos para robar, estafar y, en definitiva, medrar; la burla al mercader en sus líneas generales; algunos elementos que sirven de inspiración para los demás episodios, sin olvidar el aparente remordimiento. Todas estas características unidas serán precisamente las que se encuentren después en la picaresca femenina y pasen en buena medida a la novela cortesana. No significa este hecho que Baltasar de Collazos ejerciera de modelo de autores como López de Úbeda o Castillo Solórzano, sino que la confluencia de géneros tuvo lugar durante la segunda mitad del Xvı y dio como resultado la aparición de unas protagonistas literarias semejantes aunque no dependientes unas de otras. ¿Casualidad? No, más bien evolución natural. A quien conociera las tres tradiciones no le resultaría difícil relacionarlas y unificarlas. Esto es lo que hicieron el autor de El Crotalón, Baltasar de Collazos y, casi cuarenta años después, López de Úbeda, quien sí mostró ya el camino a sus continuadores.

En conclusión, la tan traída relación de la obra de Baltasar de Collazos con el género picaresco existe, no cabe duda, y es Úrsula, la prostituta de raigambre aretiniana, el personaje más cercano a lo que será el pícaro, o en este caso pícara. Si bien los caballeros reúnen algunos rasgos que permiten relacionarlos con el Lazarillo, especialmente Fabián (véase nota 59 más arriba), su delito no pasa de vivir una mentira que casi nadie cree. En cambio, la figura de Úrsula se opone a la de estos precisamente por haber logrado instalarse en una cómoda situación a partir de una vida basada en el engaño y la estafa.

Pero en ningún caso puede afirmarse que los Coloquios sea una obra picaresca. Es un diálogo en cuyo seno se incorpora un relato de protagonista apicarada, pues como ya se ha dicho, ni siquiera cuenta Úrsula su vida por entero, sino tan solo tres breves anécdotas que sirven para ilustrarla. Podrían aplicarse a este caso las palabras de Gallardo acerca de los Eremitae: «una lectura hecha a la luz de la picaresca resulta enormemente fecunda para hacer emerger la riqueza literaria de este diálogo, si no hermano, quizás hermanastro o primo de las novelas de pícaros». ${ }^{59}$ No se debe, sin embargo, pasar de ahí. Si Salas Barbadillo y Castillo Solórzano se valían del ejemplo de la literatura cortesana para insertar la narración picaresca y poder así gestionar las diferentes visiones dentro de la obra, Collazos se sirve del diálogo para presentar directamente diversos puntos de vista y, siempre dentro de este molde, reserva algo más de espacio a la narración en primera persona de la prostituta, para regresar después al modo dialogado.

59. Gallardo (2001: 116). 


\section{Bibliografía}

Arredondo Sirodey, Ma Soledad, "Pícaras. Mujeres de mal vivir en la narrativa del Siglo de Oro", Dicenda. Cuadernos de filología hispánica, 11 (1993), págs. 11-33.

—, "De la picaresca menor al "costumbrismo": la Guia y aviso de forasteros... y otros escarmientos», Edad de Oro, 20 (2001), págs. 9-21.

—, Ma Soledad, «Introducción», en Alonso de CASTILLO SOLÓRZANO, La niña de los embustes, Teresa de Manzanares, Barcelona, Debolsillo, 2005.

Asensio, Eugenio, «Dos obras dialogadas con influencia del Lazarillo de Tormes: Colloquios, de Collazos, y anónimo Diálogo del Capón», en Cuadernos Hispanoamericanos, 94 (1973), 280-282, págs. 385-398.

Castillo Solórzano, Alonso de, La garduña de Sevilla y anzuelo de bolsas, Federico Ruiz Morcuende (ed.), Madrid, Espasa-Calpe, 1972.

—, La niña de los embustes, Teresa de Manzanares, en Picaresca femenina, Antonio Rey Hazas (ed.), Barcelona, Plaza y Janés, 1986.

—, La niña de los embustes, Teresa de Manzanares, Ma Soledad Arredondo Sirodey (ed.), Barcelona, Debolsillo, 2005.

Collazos, Baltasar de, Coloquios, en Sara Sánchez Bellido, Estudio y edición de los Coloquios de Baltasar de Collazos, Madrid, Universidad Complutense de Madrid, 2013 (disponible en e-prints de la UCM: <http://eprints.ucm. es/23811/1/T35043.pdf>).

Ferrer-Chivite, Manuel, «Baltasar de Collazos y el protopicarismo de sus Colloquios (1568)», en Jules Whicker (ed.), Actas del XII Congreso de la Asociación Internacional de Hispanistas (Birmingham, 21-26 de agosto de 1995): Estudios áureos, Birmingham, University of Birmingham, 1998, t. II, págs. 203-213.

Gallardo, Carmen, «Los Eremitae de Juan de Maldonado en el origen de la picaresca», Edad de Oro, XX (2001), págs. 105-117.

Gómez, Jesús, El diálogo en el Renacimiento español, Madrid, Cátedra, 1988.

Hanrahan, Thomas, La mujer en la novela picaresca española (2 vols.), Madrid, Porrúa-Turanzas, 1967.

López de ÚbedA, Francisco, La picara Justina, Antonio Rey Hazas (ed.), Madrid, Editora Nacional, 1977.

Ortega, Margarita, Asunción Lavrin y Pilar Pérez Cantó (coords.), El mundo moderno, en Isabel Morant (Dir.), Historia de las mujeres en España y América Latina, vol. 2, Madrid, Cátedra, 2005.

Peinador Marín, Luis J., "Construcción y significado de los Colloquios de Collazos» en Manuel García Martín (ed.), Estado actual de los estudios sobre el Siglo de Oro, Salamanca, Universidad de Salamanca, 1993, t. II, págs. 769-776.

Rey Hazas, Antonio, Picaresca femenina, Barcelona, Plaza y Janés, 1986.

—, La novela picaresca, Madrid, Anaya, 1990. 
—, Deslindes de la novela picaresca, Málaga, Universidad de Málaga, 2003.

Salas Barbadillo, Alonso Jerónimo, La hija de Celestina, en Antonio Rey Hazas, Picaresca femenina, Antonio Rey Hazas, Barcelona, Plaza y Janés, 1986.

Sánchez Bellido, Sara, "Nuevo acercamiento a las relaciones entre los Coloquios de Baltasar de Collazos y la literatura picaresca», Janus. Estudios sobre el Siglo de Oro, III (2014), págs. 27-44.

Vian Herrero, Ana, Diálogo y forma narrativa en El Crotalón: estudio literario, edición y notas, 3 vols., Madrid, Editorial de la Universidad Complutense de Madrid, 1982.

-, «Pietro Aretino y la cortesana del canto VII de El Crotalón», en Italia y la literatura hispánica, num. monográfico de Studi Ispanici, (1997-1998), págs. 57-74.

—, "El Diálogo de las Transformaciones de Pitágoras, la tradición satírica menipea y los orígenes de la picaresca: confluencia de estímulos narrativos en la España renacentista», en Jean Canavaggio (ed.), La invención de la novela, Collection de la Casa de Velázquez, 60, Madrid, Casa de Velázquez, 1999, págs. 107-128.

—, «Interlocutoras renacentistas en diálogos hispano-flamencos: la irrupción del personaje femenino en la tradición de los coloquios escolares», en Encuentros en Flandes: relaciones e intercambios hispano-flamencos a inicios de la Edad Moderna, Robert Verdonck y Werner Thomas (eds.), Amberes, Fundación Duques de Soria-Leuven University Press, 2000, págs. 157-192.

—, «La rebelión literaria de las cotorras mudas. Modelos de interlocutora femenina en la historia del diálogo» en Homenaje a Elena Catena, Madrid, Castalia, 2001, págs. 505-526.

—, «El legado de La Celestina en el Aretino español», en El mundo social y cultural en la época de La Celestina. Actas del Congreso Internacional (Pamplona, Universidad de Navarra, 21-23 junio 2001), Ignacio Arellano y Jesús María Usunáriz (eds.), Madrid-Frankfurt, Iberoamericana-Vervuert, 2003, págs. 323-354.

—, «El relato de Úrsula en los Colloquios de Baltasar de Collazos (1568): diálogo narrativo y paradoja moral» en Pierre Civil (coord.), Siglos dorados. Homenaje a Augustin Redondo, Madrid, Castalia, 2004, t. II, págs. 1427-1443.

—, «Úrsula de los Colloquios de Baltasar de Collazos (1568) y las tradiciones literarias de la interlocutora y la pícara" en "Por discreto y por amigo" Mélanges offerts à Jean Canavaggio, Madrid, Casa de Velázquez, 2005, págs. 453-470.

—, "Estudio preliminar», en Diálogos españoles del Renacimiento, Ana Vian Herrero (ed. general y estudio preliminar), Córdoba, Editorial Almuzara-Fundación Biblioteca de Literatura Universal, 2010.

Xuárez, Fernán y Pietro Aretino, Coloquio de las damas. Dialogo, Donatella Gagliardi (ed.), Roma, Salerno Editrice, 2011. 
